\title{
Distributed Generation Technologies, Cost Analysis and Power Quality Issues in India
}

\author{
Sachin Thakur* and Sunny Vig \\ UIE, Chandigarh University, Gharuan-140413, Punjab, India; \\ thakurs0648@gmail.com,sunnyleo14@gmail.com
}

\begin{abstract}
Objectives: This paper discussed the cost analysis and power quality issues by using distributed generation technology in India. Methods/Statistical Analysis: A new technology known as distributed generation has been adopted which helps in mitigate the demand of power in future. The insertion of DG in distribution system is very helpful in distant areas and small areas where the installation of transmission lines and availability of land is impossible. This paper review on the different types of Distribution technologies, their insertion cost as compared to conventional generation energy sources and power quality problems and how they useful in future to fulfill the demand of power. Findings: Previously conventional sources such as coal, petroleum, natural gas have been used for generation of electrical power. These conventional energy sources are not environmental friendly and their cost is more as compared to non-conventional energy source. As demand is increasing day by day such sources wind energy, solar energy, fuel cell etc. are helpful to fulfill the demand of electrical power. Application/Improvements: DG as a cheap source of electric generation reduces the transmission line cost, transmission losses and it is environmental friendly also and gives benefits to the consumer.
\end{abstract}

Keywords: Conventional Energy Sources, Distributed Generation, Distribution System, Non-Conventional Energy Sources, Power Quality

\section{Introduction}

The total electrical sector installed capacity in India is 305554.25 M was of 30 August 2016. During 2012-2013 the transmission and distribution losses are $23.04 \%$ but during $2013-2014$ it is $21.46 \%$ of total power energy sources for generating electricity are an alternative technology generation which is decreasing 2 . The required installation capacity would likely outstretched to be 770 GW by 2030. For diminishing gross technical and commercial losses (AT\&C) and carbon emissions, there is a requirement to include conventional and non-conventional (small scale) generation near to load centers known as Distributed Generation (DG).

\subsection{Distributed Generation}

Distributed generation is an access to small and medium power generation near its consumers and is also known as on site power generation. In distribution generation system the generation range is from several $\mathrm{KW}$ to few MW as it fulfillthe requirement of consumers, utilities and society ${ }^{\underline{3}}$. Distributed generation system is the cleanest source of generation of electrical power and is less complex. Non- conventional energy resources such as solar energy, wind energy, fuel cell etc. are the important part of the distributed generation system and give rise to economic, efficient and reliable power. As DG is different from the other power generation. Distribution

${ }^{*}$ Author for correspondence 


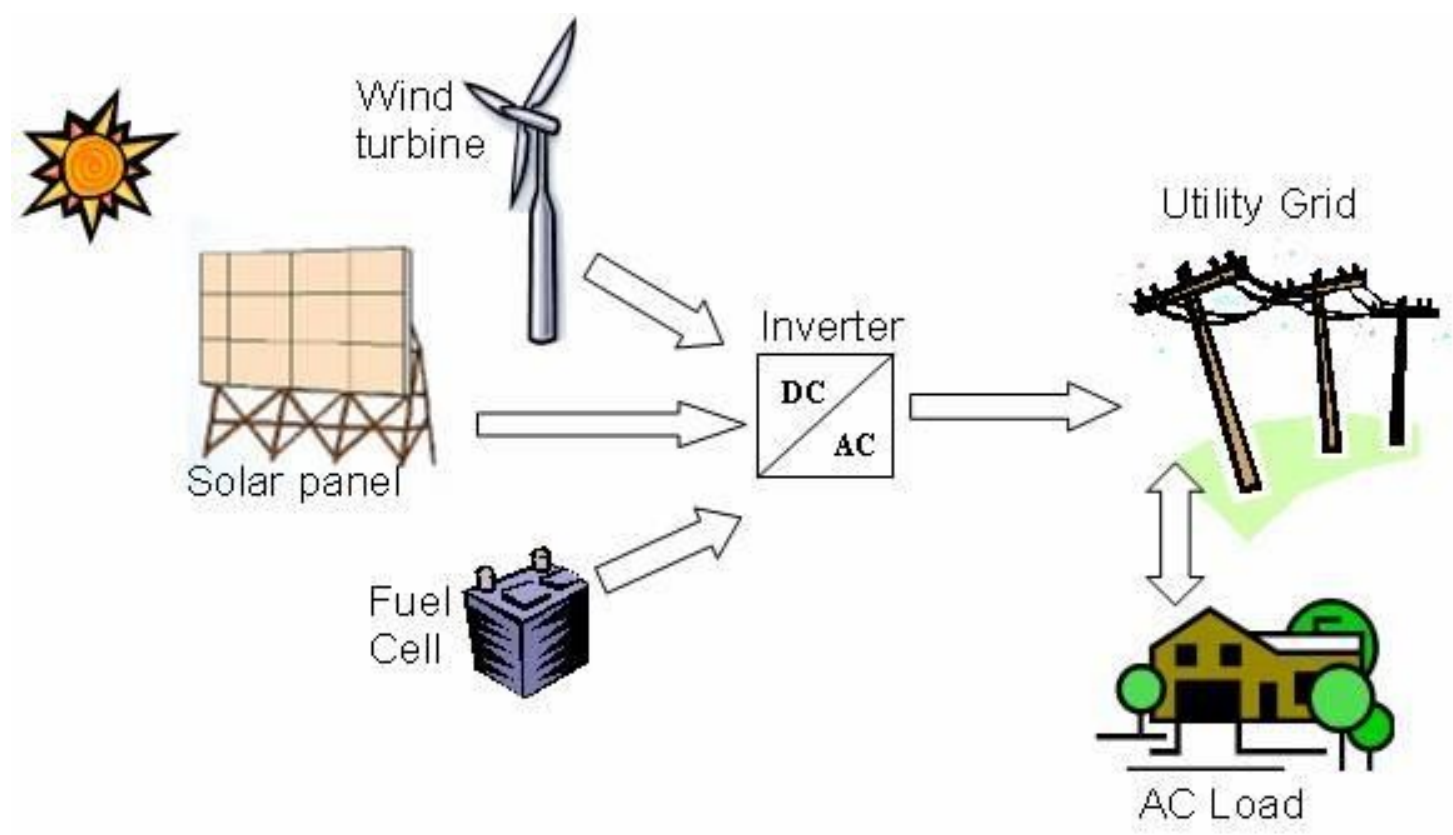

Figure 1. Overview of DG technologies ${ }^{\underline{6}}$.

energy source includes solar energy, wind energy; fuel cell etc. and these sources is prime mover in DG system ${ }^{4}$. The DG is widely available in small units, small size, and minimum cost and less installation time. The DG can be used as standby or emergency generation source and as a green power source (using renewable technology). In this paper various distribution technologies are described which leads to increase in DG and fulfill the requirement of power for future. DG is currently used by customers to fulfill their electricity needs and to reduce the demand charges by their own electric utility. DG technologies reduce the load of centralized power generating station. Today more focus is on the renewable based energy sources as compared to conventional energy sources. As non-renewable sources is decreasing day by day and also effects of these resources severe on the earth.

"DG is an electric power source connected directly to thedistribution network or on the customer side of the meter" $\underline{5}$.

\section{DG Technologies}

The different types of technologies accessible for DG based on the renewable and non-renewable energy sources as shown in Figure 1.

\subsection{Renewable Energy based DG Technologies}

- Solar

- Wind

- Geothermal

- Tidal

- Biofuel (biogas, biomass gasification, biomass cogeneration)

\subsection{Nonrenewable Energy based DG Technologies}

- Micro turbines 
- Fuel cells

- Internal Combustion (IC) engines fueled by diesel or natural gas.

For a year India has about 250-300 days unclouded. So solar energy is the best source for generation of electricity. Solar thermal and solar photovoltaic are the two kinds of solar power generation ${ }^{7}$. Solar thermal power generation utilizes the sun gleam to heat the fluid to high temperature and fluid is then flowing through the pipes. This fluid can transport their heat to water and induces steam. In turbine, Steam is then permuted to mechanical energy and generates electricity by generators. It is an unintended method of generating electricity. The efficiency of solar thermal power generation is less because of complication technology, accuracy requirement and heat loss. Solar photovoltaic power generation technology is expanding day by day. It is a straight process in which sunlight energy is directly permuted into electrical energy. The total solar installed capacity in India is 7805.34 MW as on 30.06.2016" Table 1 presents correlation for different DGs.

Table 1. Correlation of different DG according to their capacity, electrical efficiency and applications ${ }^{Z}$

\begin{tabular}{|c|c|c|c|c|}
\hline Technology & Types & Gridinterface & Capacity & $\begin{array}{l}\text { Electrical } \\
\text { efficiency }\end{array}$ \\
\hline Solar & Renewable & $\begin{array}{l}\text { DC-AC } \\
\text { Converter }\end{array}$ & $20 \mathrm{~W}-100 \mathrm{KW}$ & $15-16$ \\
\hline Wind & Renewable & $\begin{array}{l}\text { Induction } \\
\text { Generator }\end{array}$ & $200 \mathrm{KW}-2 \mathrm{MW}$ & $20-30$ \\
\hline Microhydro plant & Renewable & $\begin{array}{l}\text { Synchronous } \\
\text { generator }\end{array}$ & Upto $100 \mathrm{KW}$ & $40-50$ \\
\hline Biomass Gasification & Renewable & $\begin{array}{l}\text { Synchronous } \\
\text { generator }\end{array}$ & $3 \mathrm{KW}-250 \mathrm{KW}$ & $30-34$ \\
\hline BiogasCogeneration & Renewable & $\begin{array}{l}\text { Synchronous } \\
\text { generator }\end{array}$ & $20 \mathrm{KW}-20 \mathrm{MW}$ & $30-35$ \\
\hline Microturbines & $\begin{array}{c}\text { Non } \\
\text { Renewable }\end{array}$ & $\begin{array}{l}\text { AC-AC } \\
\text { Converter }\end{array}$ & $25 \mathrm{KW}-500 \mathrm{KW}$ & $31-40$ \\
\hline Fuel cell & $\begin{array}{c}\text { Non } \\
\text { Renewable }\end{array}$ & $\begin{array}{l}\text { DC-AC } \\
\text { Converter }\end{array}$ & $250 \mathrm{KW}-5 \mathrm{MW}$ & $36-50$ \\
\hline $\begin{array}{c}\text { I Cengines powered by natural } \\
\text { gas }\end{array}$ & $\begin{array}{c}\text { Non } \\
\text { Renewable }\end{array}$ & $\begin{array}{l}\text { Synchronous } \\
\text { generator }\end{array}$ & $30 \mathrm{KW}-6 \mathrm{MW}$ & $30-42$ \\
\hline I Cengines powered by diesel & $\begin{array}{c}\text { Non } \\
\text { Renewable }\end{array}$ & $\begin{array}{l}\text { Synchronous } \\
\text { generator }\end{array}$ & $5 \mathrm{KW}-10 \mathrm{MW}$ & $30-43$ \\
\hline
\end{tabular}


Micro-turbines are recent and evolving DG technology for small scale power generation that employs methane, natural gas, diesel as fuel. The principal benefits of this technology are small size (approximately the size of refrigerator), greater efficiency, long life, lesser electricity cost, lesser noise, small carbon emission loss, low fuel consumption and free from pollution ${ }^{-}$. Fuel cells are a DG technology that is based on chemical process for generation electricity. It utilizes hydrogen from fuels (natural gas, oil etc.); react with oxygen in atmosphere with the help of electrolyte to form water at same moment generating electricity. The benefits of fuel cell are no carbon emission, good energy conversion efficiency, no noise and robust potential to load changes ${ }^{8}$. The kinetic energy of wind from the horizontal translation is changed into kinetic energy of rotation of turbine connected to an axis by way of a number of blades. By using an electrical generator this rotational energy is converted into electrical energy. The most seeable modern source of electrical energy is wind power. Wind energy supported power generation is the better option for conservative fossil fuel to shrink carbon foot print. Figure 2 shows energy flow of wind turbine. In India, the total installed potential of wind power generation is $27151.40 \mathrm{MW}$ as of 30 June, $2016^{1}$.

Small hydro power plant is undertaken by ministry of new and renewable energy having capacities up to 25 MW. Small hydro project is also categorized as mini and micro hydro having capacities up to $2 \mathrm{MW}$ and $100 \mathrm{KW}$ respectively which can also be used as DG based power generation?. In India, total installed capacity of small hydro power generation is $4304.27 \mathrm{MW}$ as of 30 June, $2016^{1}$.

Bio gas is combination of methane, carbon dioxide, water and hydrogen sulphide obtained throughout the anaerobic decomposition of organic matter. It can be changed into any type of thermal, electrical and mechanical energy and waste can be used as energy source for cooking and lighting. It is small scale power generation and is a renewable green energy source.

Biomass gasification is the method of changing solid biomass fuel into a gaseous combustible gas also known as producer gas through a succession of thermo-chemical reactions. A gasified system primarily consists of reactor where gas i.e. methane, hydrogen and carbon dioxide is produced and is succeeded by acooling and cleaning train.

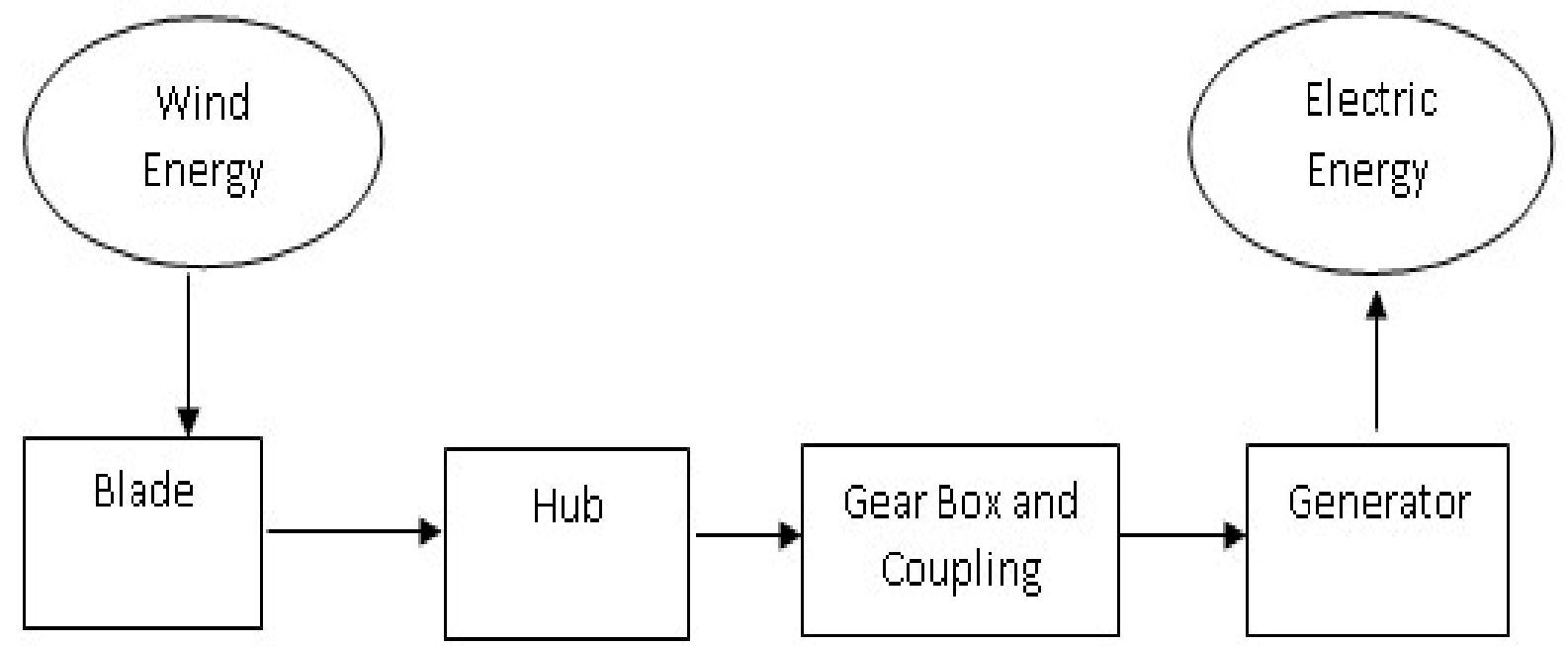

Figure 2. Wind turbine energy flow ${ }^{3}$. 
For generating electricity this producer gas as fuel for IC engines is used ${ }^{9}$. Biomass cogeneration is renewable, broadly accessible, carbon neutral and is also the ability of producing firm energy. The material used for biomass power generation contains biogases, coffee waste, jute waste; saw dirt, other agro and forestry waste. This combustible is blaze for creation of steam which rotates +the steam turbine and remnant heat can be utilized for heating application in industries which is known as cogeneration. As of 30 June, 2016 overall installed capacity of biomass cogeneration is $4860.83 \mathrm{MW}^{1}$. Estimated installed capacity can be raised up to $6000 \mathrm{MW}$ if sugar mill acquires new cogeneration technology. Bio mass cogeneration can be the better technique to fulfill the captive load.

\section{Transmission and Analysis Cost}

The generating capacity should be raised by maintaining the gap between supply and demand. Every investor chooses for the technology with moderate operation and maintenance cost $(\mathrm{O} \& \mathrm{M})$, capital cost. Figure 3 shows correlation of different technologies based on installation cost.

When juxtapose with fossil fuel based power generation, installation cost of renewable based generation are bit costly will be preferable for future because of

- Environmental friendly and clean source of energy.

- Renewable energy based power generation can become affordable among growth in technology.

- Renewable energy is easily accessible all over the world thus there are no possibility of depletion in future.

- Fuel shortage, Operation and maintenancecost for fossil fuel based generation are rising.

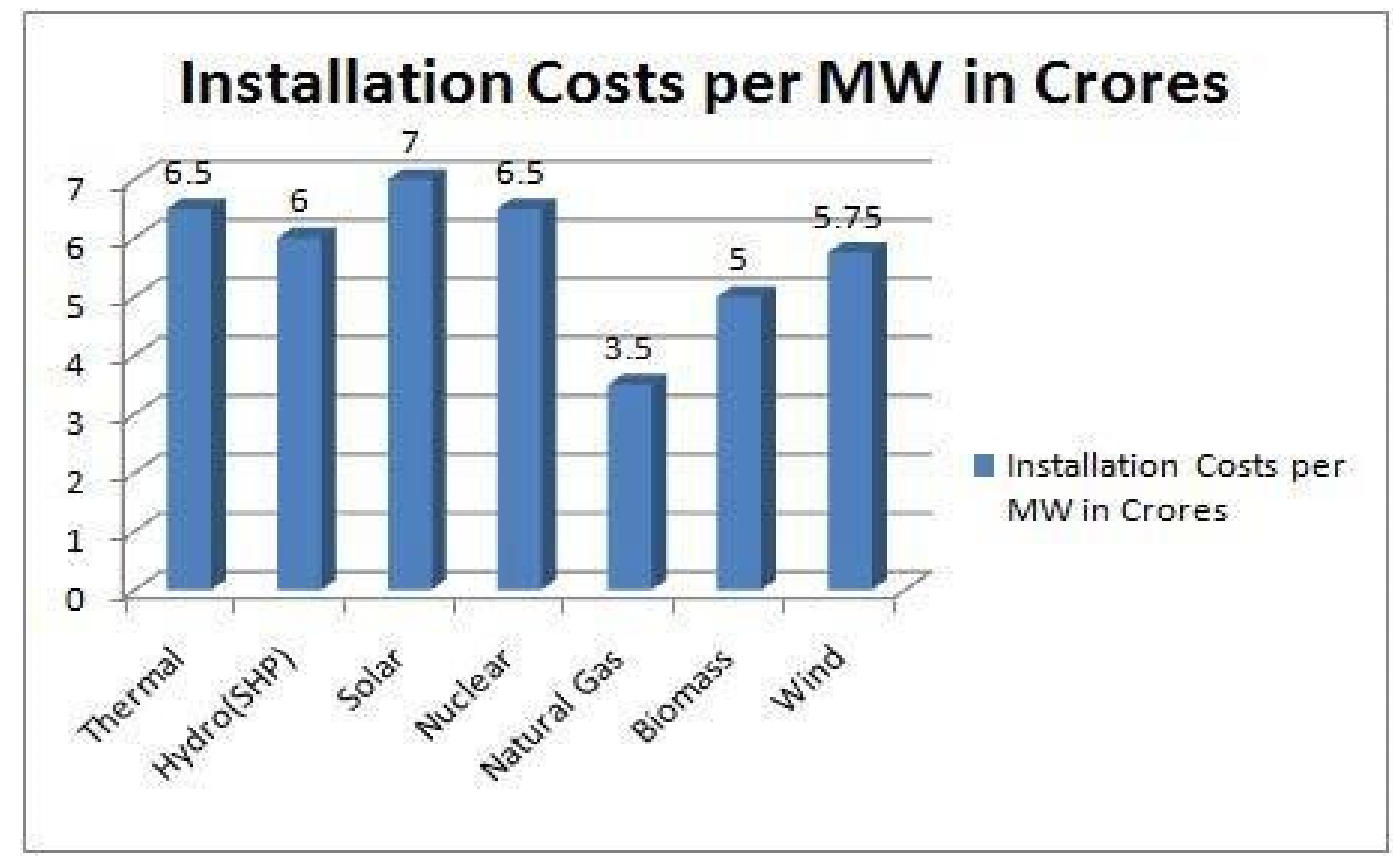

Figure 3. Correlation of different technologies installation cost ${ }^{7}$. 


\subsection{Power Quality Issues}

The main problem related to DG is their effect when coupled with grid. The power qualities issues may appear when DG is integrating with grid are:

\subsubsection{Voltage Flickering}

It is defined as the observable change in lightingof lamp due to variationin voltage. These variations are due to sudden variation in DG output and are the common issue related with DG integration to distribution network which causes failure and reduction in life of apparatus may occur. This difficulty can control by limiting the load on network, static VAR compensator and quick response reactive compensation techniques ${ }^{10}$.

\subsubsection{Harmonics}

Nonlinear load, solar and fuel cell DG technologies use power electronics converter (dc-dc converter) that creates harmonics. The effect of harmonics is increase in power loss including utility and customer equipment, apparatus failure and interference with the communication circuit. Modern IGBT converter based on PWM technique are used to mitigate the effect of harmonics and provide pure output current $\frac{10}{}$.

\subsubsection{Voltage Unbalance}

It is the voltage variation in power system and phase differences between them are unequal. When link to distribution network, voltage unbalance can occur in single phase solar (PV) DG. If additional unit are connected to network this will lead to contingencies.

\subsubsection{Reactive Power Compensation}

When current and voltage are not in phase then reactive power occur in A.C. circuit. In rural areas mostly irrigation pump load occurs the whole day. Voltage sag and high distribution losses are the result of these absorbed reactive powers. Generators, synchronous condenser and electrostatic equipment such as capacitor provide reactive power which directly affects electric system voltage.

\section{Role of Transformer in Distributed Generation}

The transformer connections play a very important role in how a small DG unit affects the utility system and vice-versa. Utilities are facing lot of challenges while inter-connecting DG with power distribution system. Types of transformer connections are also one of the challenges related to DG. As level of generating voltage is not very high while using DG, so the transformer has to be small in size, insulation required is also less. This paper also proposed a method that Mustard oil can be used instead of Mineral oil for insulation and cooling of transformer which results in increased efficiency and life of transformer.

\section{Conclusion}

Demand of electricity is increasing day by day. Distributed generation carbon foot prints and AT\&C losses are reduced by maintaining the balance between supply and demand. When compared with conventional power generation methods the installation cost of DG equipment are high but with time and implementation the cost is likely to get reduced in future. This paper also proposes a method to improve the efficiency and life of DG transformer, which plays a key role in DG.

\section{References}

1. Government of India Ministry of Power Central Electricity Authority New Delhi. 2016. Available from: http://www.cea. nic.in/reports/monthly/installedcapacity/2016/installed_c apacity-08.pdf

2. Government of India Ministry of Power Central electricity Authority New Delhi. 2016. Available from: http://www. cea.nic.in/reports/monthly/executivesummary2016/exe_ summary-07.pdf

3. Roy NK, Pota HR. Distribution grid codes: Opportunities and challenges. IEEE Power-Tech (POWERTECH); Grenoble. 2013. p. 1-6.

4. Shuang H, Xiang GQ. Review of impact of distributed generation on distribution system. Proceedings of International 
Conference on Advanced Power System Automation and Protection (APAP); 2011. p. 219-22.

5. Ackermann T, Andersson G, Soder L. Distributed generation: A definition. Electric Power System Res. 2001; 57:195-204. Crossref.

6. Distributed Generation. 2005. Available from: http://fec. eng.monash.edu.au/2005/dg/dg.php

7. Yamujala S. Present Scenario of Distributed Generation in India - Technologies, Cost Analysis and Power Quality Issues. Innovative Applications of Computational Intelligence on Power, Energy and Controls with their Impact on Humanity (CIPECH); 2014. p. 417-21.

8. Hongkai L, Chenghong X, Jinghui S, Yuexi Y. Green Power Generation Technology for Distributed Power
Supply. Proceedings IEEE China International Conference on Electricity Distribution (CICED); Dec 2008. p. 1-4. Crossref.

9. Small Hydro Power Programme. 2015. Available from: http://mnre.gov.in/schemes/grid-connected/smallhydro/

10. Ackermann T, Knyazkin V. Interaction between distributed generation and distribution network: Operation aspects. Proceedings IEEE Transmission and Distribution Conference and Exhibition: Asia Pacific; Oct 2002. p. 135762. Crossref. 